\section{KONTRIBUSI NILAI SEJARAH DAN BUDAYA DALAM \\ PENGEMBANGAN SUMBER DAYA MANUSIA MENUJU \\ PEMBANGUNAN DAERAH MALUKU}

\author{
Dra. Florence Sahusilawane M.Hum
}

\section{PENDAHULUAN}

Keanekaragaman budaya merupakan kekayaan sosial yang patut disyukuri masyarakat Maluku yang ahdir sebagai komunitas adat. Kenyataan ini sebagai suatu relitas yang muncul sebagai suatu proses interakaksi sosial. Sebagai salah satu komunal yang berpegang pada nilai-nilai budaya dan adat, semestinya menjiwai nilai-nilai itu dalam perilaku setiap hari. Secara sadar kita telah melewati suatu proses penyimpangan terhadap nilai-nilai adat dan budaya yang pernah tumbuh dan berakar dalam kehidupan orang Maluku. Konflik sosial yang terjadi beberapa waktu lalu telah meluluh lantakan hakekat budaya yang merupakan identitas dan jati diri orang Maluku yang sangat terkenal dengan keramahan dan kekerabatannya. Hal ini memberi agambaran kepada kita bahwa sesungguhnya kesadaran terhadap sejarah dan nilai-nilai budaya yang diwariskan oleh para leluhur telah menaglami pembiasan dan dostorsi dalam kehidupan masyarakat Maluk dan mendorong terjadinya segresi yang akan berujung pada disintegrasi bangsa.

Kurangnya informasi masyarakat Maluku akan buday lokalnya membuat ketahanan diri menjadi rapuh. Nilai-nilai dan kesejarahan yang esensial ayng sesungguhnya dapat memperkuat jati diri serta persatuan dan kesatuan orang Maluku semakin terkikis, seiring dengan perkembangan dan modernisasi juga merusak tatanan kehidupan orang Maluku dari segi etika dan moral. Selain itu pendidikan kebudayaan dalam keluarga dan masyarakat kurang mendapat prioritas dari setiap individu.Nilai-nilai kekerabatan dan tata krama saling menghormati juga mulai terkikis.

$1 \quad$ Kepala Balai Kajian Sejarah dan Nilai Tradisional Propinsi Maluku dan Maluku Utara
Dra. Florence Sahusilawane, M.Hum, Kontribusi Nilai Sejarah dan Budaya Dalam Pembangunan.....

Globalisasi dan modenisasi yang mendorong terjadinya transformasi nilai-nilai baru turut memperngaruhi ketahanan budaya orang Maluku.Sesungguhnya bila disadari kearifan lokal merupakan pendukung terbentuknya kearifan nasional. Hal ini tersirat dalam Bhineka Tunggal Ika yang meruapakan falsafah hidup bangsa Indonesia yang hidup dalam keanekaragaman budaya dan adat istiadat serta menghargai pluralisme.

Pembangunan suatu bangsa atau suatu daerah mestinya mengacu pada kultur yang meruapakan identitas, sehingga dapat memproyeksilkan realitas masa yang akan datang, dan tidak mengalami disorientasi dalam pembangunan itu sendiri. Peristiwa sejarah masa lampau yang terbingkai dalam sejarah lokal yang memiliki nilai persatuan, kehidupan yang harmonis, bahu membahu melawan imperialisme dan kolonialisme mesti dijadikan spirit utnuk mengisi pembangunan itu sendiri.

\section{PERMASALAHAN}

Kearifan lokal dan nilai-nilai universal yang membentuk relasi sosial yang sebelumnya terpelihara dan berlangsung akrab anatr masyarakat Maluku yang majemuk diwarnai suasana kekeluargaan (harmonis) mengalami distorsi yang cukup parah sehingga menyebabkan instabilitas sosial dan keamanan. Kekuatan kohesi sosial yang merupakan perekat keutuhan masyarakat sebagai suatu kesatuan warga bangsa dan anak daerah, berada pada tingakt yang cukup mengkhawatirkan. Kenyataan ini terindikasi dari adanya jarak sosial (social distance) antar warga, antar kelompokk masyarakat, yang terutama berorientasi pada nilai-nilai ideologi sektarian.

Berdasarkan realitas hidup yang dialami saat ini, harus diakui nilai-nilai yang mewakili kerukunan, toleransi, dan persaudaraan, dan sebagainya luntur akibat ketidaktahuan pendukungnya sendiri sementara di lain pihak nilai-nilai abru akibat perkembangan kehidupan masyarakat belum dapat diterima secara utuh mengakibatkan jati diri orang Maluku menjadi labil. Jika terus dibiarkan maka masyarakat adat di Maluku akan mengalami proses penghilangan identitas sehingga mesti dilakukan sebauh pengkajian dan sosialisasi tentang kontribusi nilai-nilai sejarah dan nilai-nilai budaya lokal dalam kaitan dengan perkembangan sumberdaya manusia maupun pembangunan daerah Maluku itu sendiri. 


\section{III, KONTRIBUSI NILAI SEJARAH DAN BUDAYA}

Nilai-nilai sejarah dan budaya di Maluku memiliki potensi untuk mengembangkan sumber daya manusia yang berakhlak dan berbudi pekerti luhur sekaligus sarana untuk menopang pembangunan. Dalam upaya recovery Maluku pasca konflik peranan nilai-nilai sejarah dapat diketahui melalui peristiwa sejarah (lokal dan nasional) maupun tempattempat bersejarah dan unkapan-ungkapan tradisional yang mampu mengintegrasikan masyarakat dan mengembalikan identitas orang Maluku. Demikian pula dengan berbagai kearifan lokal yang berkaitan dengan keharmonisan hidup, ketertiban sosial serta lingkungan alam sekitarnya.

1. Kontribusi Nilai Sejarah

a. Bagi masyarakat di pulau Marsela ada istilah Limuk Limor Kweunun Kweamam yang memiliki arti 'susah senang atau hidup mati sama-sama bergandeng tangan'. Istilah ini digunakan pada saat orang-orang Marsela melawan kaum kolonial. Makna yang terkandung dalam istilah adalah persatuan dan kesatuan untuk menghadapi suatu masalah serta memberikan semangat untuk menyelesaikan masalah itu secara bersama-sama.

b. Sejarah terbentuknya Negeri-negeri adat yang merupakan migrasi besar-besaran dari pulau Seram. Seperti di pulau Saparua misalnya tiga Negeri Bersaudara (adik berkakak) yaitu Iha, Tuhaha, dan Ulat.

c. Sejak dahulu orang Maluku sudah dikenal dengan jiwa pemberani, kstria dan (kabaresi). Pewarisan nilai ini dimulai dari sebuah organisasi rahasia (Kakehang) yang melatih anak-anak muda laki-laki (anggota-anggotanya). Nilai-nilai dan jiwa pemberani itu terkadang terimplementasi dalam ungkapan-ungkapan sehari-hari seperti gigi ganti gigi, os por os atau beta par beta, subasa lebe bae mandi sakali, yang menggambarkan keberanian tahan uji dan semangat juang yang tinggi,. Sesungguhnya praktek-praktek dalam organisasi kuno ini tidak cocok dengan kondisi saat sekarang, namun yang mesti dicontohi ialah, semangat pemebrani (kabaresi) dan jiwa patriotismenya kepada bangsa dan negara.

d. Perlawanan rakyat Maluku (Islam dan Kristen) terhadap kaum kolonial misalnya, dalam perang Hatuhaha, menunjukan adanya semangat persatuan-kesatuan itu dipelihara melalui ikatan pela antar Negeri Tuhaha dan Negeri Ruhumoni.

e. Tempat-tempat bersejarah dan situs seperti Baileo Negeri Haria yang dijadikan sebagai baileo pulu, dipakai untuk melakukan musyawarah seluruh kapitan dan upu latu sejazirah Lease mencetuskan 17 pasal keberatan dan tempat untuk mengatur strategi melawan kaum kolonial. Juga Gunung Saniri (yang sekarang dijadikan tempat untuk pembakaran obor Pattimura).

f. Bangunan-bangunan kolonial (benteng, gereja, kantor) meninggalkan nilai historis. Bangunan-bangunan ini tidak hanya dikenal dengan arsiteknya yang unik tetapi lebih daripada itu, bangunan ini menjadi saksi sejarah bukti kelaliman dari sang penjajah yang menggambarkan penderitaan para leluhur di waktu dulu. Oleh sebaa itu apra leluhur masa lalu menggalang persatuan bahu membahu melakukan perlawanan. Saat ini bangunan-bangunan sejarah itu dapat dijadikan sebagai objek pariwisata mancanegara dan wisatawan domestik.

2. Kontribusi Nilai Budaya

a. Budaya pela dan gandong di Maluku tenagh dan keberadaan negeri-negeri adat di pulau Ambon menunjukan adanya kekerabatan yang muncul untuk penyelesaian sebuah peristiwa atau masalah, atau bisa juga karena adanya pertalian darah (genologis). Misalnya Tuhaha dan Rohomoni, batumerah dan Passo, serta Hutumuri, Tamilouw, dan Siri-sori Islam. Hubungan ini biasanya terjadi pada Negri Salam dan Sarani maupun antar negeri yang memiliki agama yang sama. Sesungguhnya nilai ini patut dimaknai sebagai nilai-nilai unviersal yang dapat dikembangkan dalam kehidupan berbangsa dan bernegara.

b. Kida Bela, di Maluku Tenggara, khususnya pada masyarakat Tanimbar sam dengan Pela Gandong . sanggup membuat orang untuk tidak saling berkelahi, tidak bercerai berai, tidak membuat tindakan-tindakan yang menimbulkan keresahan dalam masyarakat. Selain itu juga dapat menyelesaikan pertentangan dan mengeliminir konflik. 
c. Tea Bel, di Kei mengandung ikatan perjanjian persahabatan antar kampung di mana iaktan perjanjian tiupun menggunakan darah, sehingga memiliki nilai yang kuat, dan tidak boleh dilanggar oleh setiap pemangkunya.

d. Twan, yakni sapaan atau salam bagi masyarakat di pulau Marsela (bisa juga Kalwedo oleh masyarakat Babar) yang berarti selamat atau baik. Istilah lokal ini memiliki nilai untuk memperkuat persatuan dan kesatuan serta mengigatkan merka pada janji dan nilai-nilai yang diwariskan oleh para leluhur.

Sesungguhnya nilai-nilai tradisional itu masih dimiliki oleh masyarakat di negeri-negeri adat. Selain itu interaksi yang muncul dalam masyarakat masih menunjukan adanya pengakuan terhadap budaya itu, walaupun mulai mengalami sedikit penyimpangan. Kekentalan dalam kekrabatan dirasakan pada saat dilaksanakannya uapcara-upacara adat, misalnya panas pela, fangea kidabela, pelantikan raja dan bentuk upacara-upacara adat lainnya yang menggambarkan keharmonisan serta keramahtamahan orang yang memiliki budaya-budaya tersebut.

Selain Pela, Kidabela, Tea Bel, dan Twan yang mengandung nilai persaudaraan juga ada istilah-istilah lokal yang memaknai nilainilai tolong menolong misalnya: Masohi di Maluku Tengah, Nekohora di Babar, maren dan Weer Warat di Kei, dan teren di Kisar. Bentukbentuk budaya tolong menolong atau gotong royong ini berkaitan dengan kepentingan seorang atau kepentingan bersama.

Pendukung kebudayaan di Maluku terdiri dari ratusan sub suku, yang dapat diindikasikan dari pengunaan bahasa lokal yang diketahui masih aktif dipergunakan sebabanyak 117 dari bahasa lokal yang pernah ada kurang lebih 130 -an (Renstra Propinsi Maluku, 2003-2008:40). Meskipun masyarakat di daerah ini mencerminkan karakteristik masyarakat yang multi kultur, tetapi apda dasrnya mempunyai kesamaan-kesamaan budaya sebagai representasi kolektif. Kewang dan Sasi merupakan pranata-pranata adat yang ad dalam kehidupan masyarakat Maluku dan memiliki fungsi melindungi hakhak tiap orang atas petuanannya, serta terpelihara potensi alam yang dimiliki.

\section{PENUTUP}

Seiring dengan perkembangan zaman dan berkembangnya nialinilai baru dalam kehidupan masyarakat Maluku, mestinya penanaman nilai-nilai sejarah lokal dipertajam untuk mengembalaikan ingatan koletifa orang Maluku tentang budaya dan identitasnya. Suatu kenyataan yang mesti dilakukan dalam upaya untuk mensinergikan pembangunan di daerah ini. Sejalan dengan upaya pemerintah daerah untuk melakukan recovery di Maluku mestinya dimulai dengan pembaharuan dalam kehidupan moral orang Maluku yang telah mengalami degradasi nilainilai adat istiadat dan budaya serta mengembalikan, pranata-pranata adat yang selama ini melemah dan cenderung tidak berfungsi mesti ditata kembali.

Konflik yang terjadi telah membuat jarak sosial dalam kehidupan masyarakat dan telah membuat proses stagnasi dalam pembangunan. Masyarakat tidak terintegrasi dan telah terjadi relokasi yang menyebabkan terjadinya penumpukan penduduk pada suatu titik dan menimbulkan kesenjangan sosial. Pengembalian nilai-nilai adat dan budaya merupakan suatu proses terapi sosial bagi orang Maluku yang mengalami Amnesia (hilang ingatan) sehingga tercipta kembali kehiduapan orang basudara di Maluku yang penuh dengan nilai kekerabatan dan persahabatan (ale rasa beta rasa, potong di kuku rasa di daging). Selain itu nilai-nilai sejarah Maluku yang dilihat dari bentuk peninggalan-peninggalan sejarah memiliki potensi untuk dikembangkan dalam uapay peningkatan kesadaran sejarah selain juga bermanfaat bagi peningkatan pendapatan asli daerah dari sektor pariwisata, dan daya jual yang tinggi bagi perekonomian di daerah ini.

Pranta tradisional yang berisikan penghoramtan kepada nilainilai kemanusiaan semestinya tidak hanya dimaknai dalam batasan pada hubungan kekerabatan atau persahabatan antar orang basudara atau berpela saja yang kemudian memberikan suatu ciri identitias terhadap kebudayaan lokal, tetapi nilai esensi dalam kebudayaan lokal itu dapat disosialisasikan kepada orang lain sehingga tercipta kehidupan yang rukun, harmonis, dan toleransi di antara sesama. Sesungguhnya makna di balik setiap hubungan kekerabatan yang dibangun itu adalah tolong menolong tenggang rasa saling percaya, dan persaudaraan, yagnmesti diimplementasikan dalam kehidupan bermasyarakat, dan berbangsa dan bernegara.

Mengakhiri makalah ini perlu dikemukakan bahwa penanaman nilai-niali kebudayaan lokal sangat penting bagi generasi muda, upaya 
ini mesti dilakukan dengan jalan sosialisasi maupun melalui proses pendidikan formal di tiap jenjang pendidikan. Dengan demikian dapat menghilangkan trauma psikis dan pembentukan moral generasi muda yang memiliki budaya yang tinggi serta mendorong terciptanya kondisi keamanan yang memungkinkan terselenggaranya pembangunan Maluku ke arah yang lebih baik. Sejalan dengan itu upaya pemerintah untuk mengejar ketertinggalan dapat dicapai melalui suatu penciptaan kondisi masyarakat yang aman, damai yang mendorong masuknya investor asing ke Maluku, dan pemberdayaan sektor pariwisata ayng berbasis nilai-nilai sejarah dan budaya Maluku.

\section{DAFTAR PUSTAKA}

Anonim, 2003-2008

Renstra Provinsi Maluku 2003 - 2008

Coley, F. L., 1987

Mimbar dan Tahta: Hubungan Lembaga-Lembaga Keagamaan dan Pemerintahan di Maluku Tengah, Jakarta: Pustaka Sinar Harapan

Sahusilawane, F., dkk 2002

Budaya Pela dan Gandong Dalam Kehidupan Masyarakat Ambon, Maluku Tengah, Departemen Pendidikan Nasional, Direktorat Jenderal Kebudayaan, Balai Kajian Sejarah dan Nilai Tradisional Porpinsi Maluku dan Maluku Utara

Yohanes, Ohoi Timu, 1983

Beberapa Sikap Hidup Orang Kei Antara Ketahanan Diri dan Proses Pembaharuan: Suatu Studi Antropologi Budaya Pastoral, Tesis Sarjana pada Sekolah Tinggi Seminari Pine Leng Manado.

Titahena, Anastasia,

Tnabar Ilaa Dalam Upacara Fargea Kidabela Seabagai Pencerminan Kerjasama Antar Desa di Maluku Tenggara. Departemen Pendidikan dan Kebudayaan, Direktorat Jenderal Kebudayaan, Balai Kajian Sejarah dan Nilai Tradisional Propinsi Maluku

Tim Penelitian, 2004

Pemulihan dan Penataan Budaya di Maluku, Ambon: Kementerian Kebudayaan dan Pariwisata, Balai Kajian Sejarah dan Nilai Tradisional Propinsi Maluku dan Maluku Utara.

Pattykayhattu, J.A, et.al, 2000

Budaya Masohi (Gotong Royong) dan Perluasannya. Ambon: Departemen Pendidikan Nasional, Direktorat Jenderal Kebudayaan, Balai Kajian Sejarah dan Nilai Tradisioanl Propinsi Maluku dan Maluku Utara. 